\title{
Introduction: Crime and Deviance through the Lens of Popular Culture
}

\section{Dimitris Akrivos}

Canterbury Christ Church University

\section{Alexandros K. Antoniou}

University of Essex

Peter Weir's film The Truman Show tells the story of Truman Burbank, a man unaware of the fact that he has been the star of his own reality TV show since the day he was born. When a journalist asks Christof, the director of the show, how he has managed to keep this secret from Truman for so long, he replies: 'We accept the reality of the world with which we are presented. It's as simple as that.' Truman thinks he is an ordinary man living an ordinary life, but his entire world is a lie: the place where he lives is a television set with cameras hidden everywhere; everyone around him including his wife and friends are actors playing their roles. When he finally finds out the truth, he decides to break free from his comfortable mediated 'cage' and explore what lies beyond the world Christof and his team have built for him. Released in 1998, The Truman Show was at the time regarded mainly as an exaggerated satire of the increasingly popular reality television and the media's intrusion into people's lives (Miller, 2018). Two decades later, Weir's film seems largely prescient. This is not just because of the plethora of reality television shows like Big Brother, Survivor, The Real Housewives and Keeping up with the Kardashians currently being produced and airing worldwide. It is mainly because the media have, in the $21^{\text {st }}$ century, become such an integral part of our everyday lives that many of us are effectively producing and starring in our very own reality shows through our constant Facebook posts, YouTube videos, Snapchats and so on.

In line with Christof's aforementioned statement about accepting the reality of the world we are presented with, the media's influence in this process is crucial and often sought after. However, although Truman was successful in escaping the mediated reality he was living in, this is almost impossible to achieve nowadays. Contemporary popular culture - in the form of 
Netflix, Twitter and Instagram stories, the new iPhone, Taylor Swift's latest album, a game of Fortnite or even Hulk Hogan's sex tape - is pervasive and has real-life implications. On the day these lines are being written (30 May 2018), Donald Trump, former host of The Apprentice, posted a Twitter message that reads, 'Great meeting with @ KimKardashian today, talked about prison reform and sentencing.' This is not another Truman-Show-like satire involving two reality TV stars casually exchanging views on crime and justice-related issues. The accompanying picture of Trump and Kardashian in the White House's Oval Office serves as a good reminder of that. This is 2018 and Donald Trump is the $45^{\text {th }}$ President of the United States; the \#MeToo social media movement has given a voice to victims of sexual assault, going as far as to challenge Brett Kavanaugh's US Supreme Court nomination; and an increasing number of true-crime documentaries like Netflix's Making a Murderer put real-life crime cases under a microscope, considering possible miscarriages of justice while attracting millions of viewers along the way. Before we look more closely at the complex, modern-day connections between crime, deviance and popular culture, it is essential to first briefly explore the historical context in which this concept of 'popular culture' emerged.

Classic and contemporary scholarly attempts to define popular culture often emphasise its links to the capitalist market economy of modern societies, largely considering it a highly commercial, homogenised culture which is mass produced for mass consumption. Key theorists of the 'culture and civilisation' tradition (which dominated the relevant cultural discussions until the middle of the $20^{\text {th }}$ century) saw this allegedly inferior culture of the masses as a serious threat to the high culture of the elite and likely to lead to anarchy (Arnold, 1960; Leavis, 2009). The Frankfurt School regarded the homogenising power of popular culture as a means to achieve conformity and maintain social authority (Horkheimer and Adorno, 2006). In the second half of the $20^{\text {th }}$ century, however, the rise of postmodernism led to the rejection of 'the great divide' between high art and popular culture (Huyssen, 1986), focusing primarily 
on the heterogeneity rather than homogeneity of the latter and the opportunities it offers for a plurality of voices to be heard (Lyotard, 1984). Whether involving a juxtaposition between high and low, dominant and subordinate cultures or even as an 'anything goes' culture breaking away from the cultural elitism of modernism, the notion of popular culture is inextricably intertwined with cultural conflict and debate (Storey, 2018).

Although its entertainment value should not be underestimated, $21^{\text {st }}$-century popular culture does not merely seek to provide an escape from mundane reality but reflects real-life anxieties and constitutes a dynamic arena where the nature, causes and appropriate responses to different social problems are defined, debated and negotiated (Maratea and Monahan, 2016). Cultural criminology has drawn attention to the popular cultural portrayals of crime and deviance, aiming not just to explore their role in shaping public attitudes but also to closely examine the 'microcircuits of knowledge regarding crime, deviance, and the societal reaction to these phenomena'; microcircuits which 'often feed each other or blend into one another' (Websdale and Ferrell, 1999, p. 349; emphasis in the original). As the boundaries between social and media reality become increasingly fluid in our postmodern world, images 'bounce endlessly one off the other' creating an 'infinite hall of [mediated] mirrors' (Ferrell, 1999, p. 397). Therefore, any attempt to understand the meaning of crime and deviance, and the politics of social control outside their popular cultural representations, would be seriously deficient.

Although in recent years there has been a growing scholarly interest in how crime and deviance are represented in popular culture and what the potential social consequences of such representations are, it has been difficult for academic research to keep up with the everexpanding and multi-faceted sphere of the $21^{\text {st }}$-century popular culture. This collection explores the links between crime, deviance and popular culture in our highly-mediatised era with a view to offering an insight into the cultural processes through which different practices acquire a criminal or deviant status and are often identified as social problems. Adopting a 
multi-disciplinary approach, the book addresses these issues by bringing together UK and international scholars with different areas of specialisation in order to provide an up-to-date analysis of some important and topical issues in contemporary popular culture. More specifically, the collection looks at different aspects of popular culture (from fictional television shows and films to true crime podcasts and memoirs, outlaw motorcycle clubs, graffiti, sports and more), examining a wide range of relevant case studies through the lens of different theories of crime and deviance. The studies included in this collection do not seek to provide a comprehensive analysis of every single aspect of contemporary popular culture, but to offer an insight into its dynamic, fast-paced, heterogeneous landscape, advancing the existing scholarship on the subject by raising questions, introducing new perspectives and opening up avenues for further research.

The collection comprises of five thematic sections. Section One brings together chapters looking at how the detective/crime solver is represented in contemporary television and crime fiction. In Chapter One, Jakob Stougaard-Nielsen explores how the deviant female detective in Scandinavian crime fiction is used to engage audiences in considerations of social trust and equality in the contemporary welfare state. Drawing on examples of neuro-diverse detectives in Stieg Larsson's The Girl with the Dragon Tattoo and the TV show The Bridge, the research focuses on fictional representations of autism and considers the apparent paradox that socially dysfunctional and non-empathetic detectives, such as Lisbeth Salander and Saga Norén, have become globally celebrated as heroines embodying social justice and egalitarianism.

Archontoula Menti's study in Chapter Two investigates the representation of crime and criminals through the language used in two contemporary crime TV shows based on the Sherlock Holmes detective stories, Sherlock and Elementary. Combining two types of linguistic analysis, corpus linguistics and critical discourse analysis, the chapter suggests that 
the two shows follow gender stereotypes in their representation of criminals and address contemporary aspects of crime in their stories such as terrorism and organised crime.

In Chapter Three, Anna Krawczyk-Łaskarzewska examines the narrative and ideological aspects of portraying the contemporary surveillance state in the American TV show Person of Interest. The analysis highlights the inherent ambiguity of the discourse of surveillance and security. It suggests that Person of Interest goes beyond the generic confines of science fiction and crime drama in order to address the anxieties of the post-9/11 world, allegedly on the brink of technological singularity. The chapter also discusses human and nonhuman character development in the show and draws attention to the ways in which the demands of mainstream storytelling may have undermined its subversive potential.

Section Two considers popular culture as an arena where gender expectations and sexual mores are debated and negotiated. In Chapter Four, Dimitris Akrivos offers an ethnographic content analysis of ABC's American Crime, discussing the role of popular television in social problem construction and evaluating its contribution to the demarginalisation of the male rape victim. His study highlights the blaming and stigmatisation of the latter, the shortcomings of the dominant feminist framing of sexual victimisation as well as the failure of the criminal justice system to effectively handle male rape cases. The author concludes that 'socially aware' TV shows like American Crime could serve as a form of 'edutainment': they have the strong potential to push back against dominant male rape myths and offer a better insight into the victims' experiences, getting audiences much more emotionally involved than pertinent factual sources of information.

In Chapter Five, Amanda Spalding considers Gillian Flynn's commercially successful Gone Girl story and its relevance to the wider society and the law. Focusing on the backlash phenomenon, this study examines the relationship between Gone Girl and recent legal and 
political developments and debates concerning rape law. The chapter suggests that Gone Girl relies on and reinforces many of the problematic aspects of the current treatment of rape in the criminal justice system. An alternative exploration of Gone Girl as a nuanced portrayal of natural justice, especially in light of the \#MeToo movement and other popular culture developments, is also offered.

In Chapter Six, Demetris Hadjigeorgiou offers an ethnographic content analysis of three comedy dramas set in universities (Fresh Meat, Greek and Sweet/Vicious), examining how these institutions are constructed as sites of neoliberal, everyday sexuality. His study argues that the shows largely portray controversial aspects of everyday sexuality in universities (e.g. laddishness) as existing on a continuum with its enticing aspects and not as deviant or criminal outliers. Drawing on Foucauldian neoliberalism, his research examines two key dimensions of this continuum: universities as sexual markets, and sexual agency. The chapter underlines the mediated nature of contemporary sexuality and makes suggestions on how to incorporate pop cultural analysis into efforts to combat everyday sexuality's problematic elements in universities.

Section Three examines how notions of crime, justice and victimisation are made sense of in true crime narratives. In particular, in Chapter Seven, Greg Stratton considers how the pop-culture success of Serial and Making a Murderer have exposed a significant, receptive audience to the true crime genre of entertainment. It is argued that digital technologies create opportunities for audiences to commit to online 'participatory practices' supporting the claims of wrongful convictions via social media. The study explores how digital media converge with narratives of wrongful conviction to develop public perceptions of miscarriages of justice. The chapter advocates that the combination of narratives of wrongful and the digital platforms offer disruptive effects in which audiences can consume, re-consume, adapt, and respond to criminal justice issues. 
In Chapter Eight, Jean Murley discusses the growing popularity and key features of true crime memoirs with reference to four key texts: Jo Ann Beard's The Fourth State of Matter, Terri Jentz's Strange Piece of Paradise, Maggie Nelson's The Red Parts, and Sarah Perry's After the Eclipse. The chapter argues that, as the true crime genre has evolved and developed in recent years, memoirs written by survivors of violent crime have become more prominent and popular, comprising an important part of the true crime genre. It is suggested that, compared to older, more traditional true crime texts written by journalists or true crime experts, the work of true crime memoirists tends to be more heavily contextualized and often expresses criticism of the genre as a whole. The study concludes that victims and survivors have strong claims to authenticity and redefine victimhood, arguing for a feminist critique of misogynistic violence as they articulate their experiences of the aftermath of crime.

Section Four is concerned with the politics of 'mainstreaming' what were in the past largely deemed to be deviant subcultures. In Chapter Nine, Tereza Kuldova documents how outlaw motorcycle clubs have, over the decades, morphed into strong transnational organisations engaged in their own self-commodification and been labelled as organized crime groups by law enforcement. The chapter looks at the different ways in which these organisations engage the superimpositions of fact and fiction in order to mobilize new supporters. It considers why more and more people in Europe align themselves ideologically with the outlaw bikers, support them, and share their anti-establishment resentments - against the 'weak' state, 'official' media, or politicians.

In Chapter Ten, Nicola Harding looks at the influence of Web 2.0, social media and user-created content upon graffiti culture performed in cyber/space. Her research discusses social and technological advances that have prompted graffiti culture to appear 'mainstream'. Building on the works of Goffman, Burgess and Baudrillard, the study analyses images from social media accounts of graffiti writers. The author argues that online representations of 
graffiti culture are no longer necessarily based upon sensory, deviant, risk-taking associated with urban graffiti. Therefore, graffiti shared on social media cannot be considered a true representation of graffiti subculture, but a procession of simulacra, developing new forms of graffiti culture dislocated from graffiti's deviant origins.

Section Five addresses issues of racialisation and Islamophobia in popular culture. In Chapter Eleven, Megan McElhone offers a qualitative content analysis of three Australian popular media texts (The Combination, Underbelly: The Golden Mile and Down Under) that frame Middle Eastern background communities in Australia as being crime-prone. The chapter argues that these texts represent Middle Eastern background communities as having proclivities for gang membership, firearms-related violence, and disregard for police and the rule of law.

Finally, in Chapter Twelve, Alberto Testa investigates how modern sports can be framed as a deviant practice by Muslim spiritual leaders in Islamic online Fatâwâ (authoritative, yet non-binding, opinions or interpretations issued by a qualified jurist or mufti on matters pertaining to the Islamic law). The analysis suggests that, although part of the Muslim world has accepted organised sports as a symbol of the modernisation of Muslim societies, these are still largely considered deviant by cyber-imams, being viewed as clear examples of contemporary society's materialism, individualism and secularism and thereby a religious and moral distraction.

\section{References}

Arnold, M., 1960. Culture and Anarchy. London: Cambridge University Press.

Ferrell, J., 1999. Cultural Criminology. Annual Review of Sociology, 25(1), pp. 395-418. 
Horkheimer, M. and Adorno, T., 2006. Culture Industry: Enlightenment as Mass Deception. In M. Durham and D. Kellner, eds. Media and Cultural Studies: Keyworks. $2^{\text {nd }}$ ed. Boston: Blackwell. pp. 41-72.

Huyssen, A., 1986. After the Great Divide: Modernism, Mass Culture and Postmodernism. London: Macmillan.

Leavis, F.R., 2009. Mass Civilisation and Minority Culture. In J. Storey, ed. Cultural Theory and Popular Culture: A Reader. $4^{\text {th }}$ ed. Abingdon: Pearson Education. pp. 12-20.

Lyotard, J. F., 1984. The Postmodern Condition. Manchester: Manchester University Press.

Maratea, R.J. and Monahan, B., 2016. Social Problems in Popular Culture. Bristol: Polity Press.

Miller, J., 2018. Twenty Years Later, Everything Is The Truman Show. Vanity Fair, [online] 5 June. Available at: <https://www.vanityfair.com/hollywood/2018/06/truman-showanniversary-jim-carrey-peter-weir-laura-linney> [Accessed 30 May 2018].

Storey, J., 2018. Cultural Theory and Popular Culture. $8^{\text {th }}$ ed. Abingdon: Routledge.

Trump, D. 2018. Great meeting with @KimKardashian today, talked about prison reform and sentencing. [Twitter] 30 May. Available at: <https://twitter.com/realDonaldTrump/status/1001961235838103552> [Accessed 30 May 2018].

Websdale, N. and Ferrell, J., 1999. Taking the Trouble. In J. Ferrell and N. Websdale, eds. Making Trouble: Cultural Constructions of Crime, Deviance, and Control. Hawthorne, NY: Aldine de Gruyter. pp. 349-364. 